\title{
IAMJ
}

INTERNATIONAL

AYURVEDIC

MEDICAL JOURNAL

Case Report

ISSN: 23205091

Impact Factor: 5.344

\section{AYURVEDIC MANAGEMENT OF DIABETES MELLITUS - A SINGLE CASE STUDY}

\author{
Pandey Mahesh $\mathbf{H}^{1}$, Mule Pranita $\mathbf{A}^{2}$ \\ ${ }^{1}$ Associate Professor Department of Kayachikitsa), ${ }^{2}$ (MD Scholar Kayachikitsa) \\ Yerala Ayurvedic Medical College Kharghar, Navi Mumbai, Maharashtra - 410210, India
}

Corresponding Author: pranitamule8393@gmail.com

\section{https://doi.org/10.46607/iamj3508082020}

(Published online: August 2020)

Open Access

(C) International Ayurvedic Medical Journal, India 2020

Article Received: 14/07/2020 - Peer Reviewed: 05/08/2020 - Accepted for Publication: 05/08/2020

(D) Check for updates

\section{ABSTRACT}

Background: The study was intended to have a theoretical audit of the Madhumeha and its treatment specifically to the utilization of a natural drug Phalatrikadi kwatha. Madhumeha, otherwise called Diabetes Mellitus is one of the sorts of Vataja prameha, that has been considered as an incurable illness (Mahagada). Because of extravagance in etiological components it brings about the inadequate arrangement of Kapha and Meda which further continues descending through the channels of Mutravaha srotas and get confined at Basti mukha prompting the side effects like Prabhoota mutrata (polyuria), Avila mutrata (tubidity of pee) and so on. As the disease is Chirakari, it requires a compelling treatment which can be proceeded for quite a while with no evil impacts. Among the numerous treatment measures referenced, Phalatrikadi kwath has been chosen in this examination and the impact was assessed.

Method: In the current logical examination a 53 years old Male directed in Outpatient having Objections of the patient was increased thirst, frequent urination, hunger, fatigue and blurred vision. By taking a gander at the signs and appearances of complaints of patient was resolved to have Diabetes after exhortation glucose tests reports. In the current case report lenient was required to treat with ayurvedic plan under the treatment of Diabetes. Going to the OPD of YMT Ayurvedic Hospital Kharghar and treated with preliminary medication (Phalatrikadi kwatha). Patients were assessed in a time period for 15 days. FBS, PPBS with clinical sign and manifestations were tested.

Result: In the wake of assessing the absolute impacts of the treatment, it was seen that Phalatrikadi kwath alongside diet and routine gave good alleviation.

Conclusion: Significant result was observed with this treatment protocol in the management of Madhumeha. 
Keywords: Madhumeha, Phalatrikadi kwatha, vataj prameha.

\section{INTRODUCTION}

Amongst the many dreadful conditions arising because of modern-day living, Madhumeha, a comparable condition of Diabetes Mellitus. Diabetes Mellitus is a metabolic disorder in which carbohydrate utilization is reduced and that of lipid and protein enhanced due to deficiency of insulin characterized by hyperglycemia ${ }^{[1]}$. Phalatrikadi Kwatha:

Phalatrikam darunisham vishalam mustam Ch nishkwathya nishanshakalkam ।

Pibetkashayam madhusamprayuktam sarvaprameheshu samuchchiteshu I

\section{Bha.pra.m.kha.38/59}

Phalatrikadi Kwatha, as the name itself demonstrates, this plan is an herbal decoction comprising of Phalatrika or Triphala (3 fruits) as the principle fixings. Triphala is a regularly utilized mix in the treatment of different ailments. It is additionally utilized as a rejuvenator, adaptogenic, detoxifying specialist, hostile to maturing and some more. Triphala is additionally one of the fixings in the Ayurveda against diabetic prescriptions and furthermore is utilized in urinary disarranges. Phalatrikadi Kwatha is a basic plan yet exceptionally powerful in fighting Diabetes mellitus and Urinary scatters.

Also, in Charaka Samhita and Bhaishajyaratnavali it is prescribed for Prameha.

\section{Aim and Objective:}

To assess the efficacy of phalatrikadi kwatha in management of Diabetes.

Case:

Pateint name-XYZ

Age- 53yrs

Occupation- Bank job

Sex- Male

Reg No-187612

$\mathrm{C} / 0$ - increased thirst, frequent urination,

hunger,

fatigue

blurred vision.

$\mathrm{H} / \mathrm{O}-\mathrm{DM}$ since 6months (not taking any medication)

N/H/O- HTN/PTB/BA/EPILEPSY

N/H/O-Malaria/Typhoid/Dengue/Jaundice/Chikengunia

$\mathrm{N} / \mathrm{H} / \mathrm{O}-\mathrm{BT} /$ Drug allergy

$\mathrm{H} / \mathrm{O}$ - Tobacco since 40yrs

$\mathrm{O} / \mathrm{E}-\mathrm{GC}$ - Fair and afebrile

$\mathrm{P}-72 / \mathrm{min}$

BP-140/80mmof hg

Investigations: $\mathrm{BSL}-\mathrm{F}=140 ; \mathrm{PP}=216$

\section{Treatment given:}

After looking into the signs and symptoms, frequently micturition etc. were to be treated and that was achieved by phalatrikadi kwatha.

Ingredients:

Phalatrikadi kwatha:

- Haritaki-Terminalia chebula

- Bibhitaki-Terminalia bellirica

- Amalaki-Emblica officinalis

- Darunisha-Berberis aristata

- Vishala - Indravaruni-Citrullus colocynthis

- Musta-Cyperus rotundus

Method of Preparation:

- The above said ingredients are taken in equal proportions and pounded so as to get their coarse pow$\operatorname{der}^{[2]}$.

- 1 part of the powder is boiled with 16 parts of water and reduced to $1 / 4^{\text {th }}$ quantity

- The contents are filtered off and the liquid portion separated

- This decoction should be consumed hot and fresh

- Every time it should be prepared fresh

Dose (adult):

$20 \mathrm{ml}$ BD before half an HR of meal

How to use?

During administration, the decoctions should be brought to a temperature fit for consumption. To this, paste of Haridra (Curcuma longa - turmeric) 3-5 grams and Honey $\mathbf{- 1}$ spoon is added and mixed thoroughly. 


\section{Benefits:}

- Diabetes Mellitus

- Urinary disorders

- Good laxative

Investigation:

Before treatment- Date 4 Feb 2020

F BSL $-140 \mathrm{mg} / \mathrm{dl}$

PP BSL - $216 \mathrm{mg} / \mathrm{dl}$

After treatment- Date 4 Feb 2020

F BSL - $109 \mathrm{mg} / \mathrm{dl}$

PP BSL - $120 \mathrm{mg} / \mathrm{dl}$

\section{Results}

- Improvement in subjective signs and symptoms was found.

- Increased frequency of micturition (Prabhoota mutra) was decreased.

- Marked reduction in the Blood sugar level.

\section{DISCUSSION}

Patient when came to the OPD was having signs and symptoms of diabetes mellitus with reports.

For treating this patient, oral treatment of phalatrikadi kwatha was selected as per the reference of charak samhita called as sarvapramehahar yoga.

This treatment was given for 15 continuous days and patient was asked to follow proper diet.

\section{Mode of action of drug-}

The preliminary medication is demonstrated in a wide range of Prameha. Prameha is brought about by vitiation of all the three doshas i.e. Vata, Pitta and Kapha alongside ten dushyas they are Meda, Rakta, Sukra, Jala, Vasa, Lasika, Majja, Rasa, Oja and Mamsa ${ }^{[3]}$. In its clinical component there is increment in sum and recurrence of strange urination. The fundamental driver given for Prameha for the most part are inactive way of life and anomalous food propensities which is liable for the development of Aama in the body. This Aama lessens the stomach related force and vitiates the three Doshas in the body. This Aama produces Aalasyata, Tandra, Hridaya Vishudhi, Dosha Pravritti, Akulmutrata, Aruchi, Suptata ${ }^{[4]}$. Likewise, in the event that we break down the pathogenesis in present day perspective there is two kinds of instrument answerable for the DM, that is insulin safe and another is pancreatic beta cell disappointment. In both these causes, target tissue imperfection and affidavit of amyloid body are found as the primary driver. These amyloid body are found as the primary driver. These amyloid bodies store on the tissues and disturb them truly by covering the channels in this manner causing insulin resistance. These amyloid bodies are likewise answerable for apoptosis of the islet cells by two components, first by calcium deregulation and second is mitochondrial brokenness in the beta cells ${ }^{[5]}$. As with respect to the preliminary medication i.e., Phalatrikadi Kwath, the 6 medications present in it follows up on the fundamental pathology of Prameha.

The triphala has a rasayan properties ${ }^{[6]}$.

Past studies report that Triphala may exert actions similar to diabetic pharmaceutical drugs by inhibiting digestive enzymes and may decrease absorption of glucose through inhibition of glycolytic enzymes, thereby reducing blood glucose levels.

The maximum reduction in serum glucose levels was seen in methanolic extract of Berberis aristata DC at the dose of $500 \mathrm{mg} / \mathrm{kg}$. Hence the methanolic extract of Berberis aristata DC had a beneficial effect on carbohydrate metabolism in diabetic condition.

colocynthis fruit has a considerable effect on reduction in the mean serum level of HbA1c and FBS in patients with the type II diabetes. Although the hypoglycaemic effect of C. colocynthis has been reported by experimental studies

Oral daily administration of $500 \mathrm{mg} / \mathrm{kg}$ of the extract of Cyperus rotundus (once a day for seven consecutive days) significantly lowered the blood glucose levels. This antihyperglycemic activity can be attributed to its antioxidant activity as it showed the strong DPPH radical scavenging action in vitro $^{[7]}$.

The preliminary medication is viewed as fit for simple organization having no side effects. Inspire of its severe and astringent taste it was all around endured acknowledged and achieve by the patients. Physiochemical examination showed that the $\mathrm{PH}$ is good for early retention in stomach as it stays acidic. Additionally, the subjective test uncovers that the Kwath contains tannins, steroids. Alkaloids in abundant. As of late tannins have gotten impressive consideration as wellbeing 
advancing segment in different plant nourishments and a few investigations have given an account of its nutraceutical properties, the condensed tannin removes demonstrated promising antidiabetics impacts. Aushadhi Sevan Kala-Pragbhakta means before meal. It is indicated in Apana Vayu Vikruti, Adha (lower) Kaya (body) Vikaras (Disease), Meda (fat).

\section{CONCLUSION}

The modern edge idea of DM ensnares the debilitation of sugars (Kapha) and fat (Meda), and protein (Mamsa) digestion. The old-style depiction had not contacted the idea of insulin; however, they have more extensive idea of Agni which incorporates all catalysts and hormones liable for all the metabolic exercises of the body. Also, ramifications of insulin in DM has not completely prevailing with regards to clearing the questions. Thus, all Pramehas (counting Madhumeha) can be viewed as metabolic issue showed as physical variations from the norm of urination. Despite huge headway of current arrangement of medication i.e., oral hypoglycaemic specialist and insulin, till date there is no such therapeutic cures attributable to its multifaceted nature. Furthermore, still researchers are battling to look through a powerful and innocuous treatment. So, to have a sheltered and successful Medicare for a drawn-out use, Phalatrikadi Kwath, turns around or breaks the Samprapti is perfect for the specific sickness. The examination affirms that Phalatrikadi Kwath is successful in treatment of Madhumeha as it has the property of Aama Pachana. Alongside this Kwath the Pathya and lack of concern are similarly significant in controlling diabetes. Along these lines Phalatrikadi Kwath treats the fundamental pathology of type $2 \mathrm{DM}$ and unquestionably decreases the manifestations of the ailment that incorporate polyuria, weakness, muscle cramps, polydipsia, FBS and PPBS.

\section{REFERENCES}

1. Williams Textbook Of Endocrinology (12th Ed) Philadelphia: Elsevier/Saunders Pp.13711435.ISBN978-14377-0324-5.

2. Sharangdhar Samhita Of Acharya Sharandhar, Jiwanprada Hindi Commentary By Dr. Smt Shailaja Shrivastav, Chaukamba Orientalla Varanasi, Fourth
Edition 2005, Madhyamkhand, Chapter 2, Pp152, Shlok 111.

3. Charak Samhita Of Agnivesha By Charak And Dridhbala, With Introduction By Shri Satyanarayan Sastri, With Hindi Commentary By Pt, Kasiinath Sastri And Dr. Gorakhnath Chaturvedi, Second Part, Chaukamba Bharti Academy Varanasi, Reprint 2011, Prameha Chikitsa Chapter 6, Pd229, Slok8.

4. Kayachikitsa 2nd Part, By Prof Ram Harsh Singh, Edition 2007, Chukambha Sanskrit Pratisthan, Delhi.

5. Westermark P. Andersson A, Westermark GT Islet Amyloid Polypeptide, Islet Amyloid, And Diabetes Mellitus Physiol Rev.2011 Jul;91(3):795-826. Doi:10.1152/Physrev.00042.2009.

6. Sushrut Samhita Of Maharsi Sushrut, Edited With Ayuveda Tatva Sandipika, Hindi Commentary By Kaviraj Ambikadutta Shastri, Chaukamba Sanskrit Sansthan Varanasi, Reprint2010, First Part, Sutra Sthan, 38th Chapter Dravya Sangrahaniya, Pd 188/ 57th Shlok.

7. Nishikant A Raut, Naresh J Gaikwad. Antidiabetic Activity Of Hydro Ethanolic Extract Of Cyperus Rotundus In Alloxan Induced Diabetes In Rats. J Fitoterapia, Volume 77, Issues 7-8, December 2006, Pages 585-588.

\section{Source of Support: Nil \\ Conflict of Interest: None Declared}

How to cite this URL: Pandey Mahesh H \& Mule Pranita A: Ayurvedic Management Of Diabetes Mellitus - A Single Case Study. International Ayurvedic Medical Journal \{online\} 2020 \{cited August, 2020\} Available from: http://www.iamj.in/posts/images/upload/4250_4253.pdf 